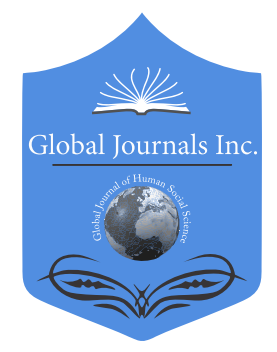

GLOBAL JOURNAL OF HUMAN-SOCIAL SCIENCE: A

ARTS \& HUMANITIES - PSYCHOLOGY

Volume 20 Issue 11 Version 1.0 Year 2020

Type: Double Blind Peer Reviewed International Research Journal

Publisher: Global Journals

Online ISSN: 2249-460x \& Print ISSN: 0975-587X

\title{
Safety Measures of Journalists During Corona Pandemic in Bangladesh
}

By Kazi M. Anisul Islam, Md. Sumon Ali, Asma Islam, Shahariar Khan Nobel, Nazmul Hasan Shajib, Mohammad Abdullah Al Mamun Chowdhury \& Rydwanul Islam

Comilla University

Abstract- Among other frontline fighters, journalists have been the first responders to the pandemic of the "COVID-19" virus. Because of following professional responsibilities, they have become highly vulnerable to get exposed to the risk. As a result, providing safety measures to them has received the highest priority at this time. It has been urged by national and international organizations and associations to media employers to provide safety measures to their respective journalists. This study aims to examine the management of media employers of Bangladesh in providing safety measures to journalists. The study interviews 48 journalists of 12 newspapers and 12 television channels, selecting one reporter and one copy editor from each media. The results reveal that the majority of journalists received inadequate, nonstandard, irregular, imbalanced, and improper safety measures while the rest got nothing because of the employer's total negligence and financial crisis. The study also shows that the media employers failed to distribute safety measures between reporters and copy editors equally. Based on the findings, the study concludes by calling for a proper safety plan to protect journalists from health risks.

Keywords: corona virus, pandemic, organizations, infectious disease, occupational health safety, human rights, equipment, economic safety.

GJHSS-A Classification: FOR Code: 190399

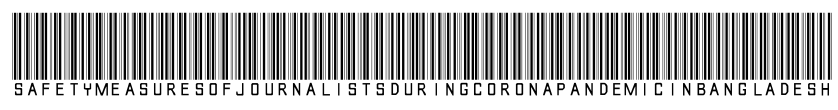

Strictly as per the compliance and regulations of:

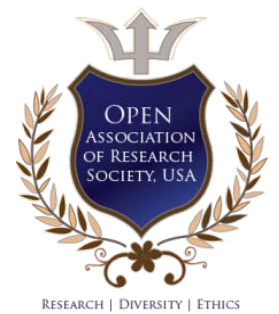

(c) 2020. Kazi M. Anisul Islam, Md. Sumon Ali, Asma Islam, Shahariar Khan Nobel, Nazmul Hasan Shajib, Mohammad Abdullah Al Mamun Chowdhury \& Rydwanul Islam. This is a research/review paper, distributed under the terms of the Creative Commons Attribution-Noncommercial 3.0 Unported License http://creativecommons.org/licenses/by-nc/3.0/), permitting all non-commercial use, distribution, and reproduction in any medium, provided the original work is properly cited. 


\title{
Safety Measures of Journalists During Corona Pandemic in Bangladesh
}

\author{
Kazi M. Anisul Islam ${ }^{\alpha}$, Md. Sumon Ali ${ }^{\circ}$, Asma Islam $^{\circ}$, Shahariar Khan Nobel ${ }^{\infty}$, Nazmul Hasan Shajib ${ }^{*}$, \\ Mohammad Abdullah Al Mamun Chowdhury ${ }^{\S} \&$ Rydwanul Islam ${ }^{x}$
}

Abstract Among other frontline fighters, journalists have been the first responders to the pandemic of the "COVID-19" virus. Because of following professional responsibilities, they have become highly vulnerable to get exposed to the risk. As a result, providing safety measures to them has received the highest priority at this time. It has been urged by national and international organizations and associations to media employers to provide safety measures to their respective journalists. This study aims to examine the management of media employers of Bangladesh in providing safety measures to journalists. The study interviews 48 journalists of 12 newspapers and 12 television channels, selecting one reporter and one copy editor from each media. The results reveal that the majority of journalists received inadequate, non-standard, irregular, imbalanced, and improper safety measures while the rest got nothing because of the employer's total negligence and financial crisis. The study also shows that the media employers failed to distribute safety measures between reporters and copy editors equally. Based on the findings, the study concludes by calling for a proper safety plan to protect journalists from health risks.

Keywords: corona virus, pandemic, organizations, infectious disease, occupational health safety, human rights, equipment, economic safety.

\section{INTRODUCTION}

$\mathrm{M}$ edia organizations have gone under a lot of threats due to the corona pandemic like all of institutions and organizations around the world. The challenges and crises have been multidimensional and global (Allsop, 2020). In corona times, media professionals have faced physical, psychological, professional, social, and economic challenges that ultimately have contributed negatively to continue regular news and programs in normalcy as before. Any outbreak can pose "'several physical, psychological, economic, and social challenges' '(Ophir, 2018, p.101). However, the COVID-19 virus, with its highly infectious characters, has put more pervasive impacts on the media industry (Adriano, 2020). As a result, the times

Author $\alpha$ : Lecturer, Dept. of Mass Communication and Journalism Comilla University, Cumilla, Bangaldesh. e-mail: kazicou@gmail.com Authoro: Newsroom Editor, Channel l, Bangladesh.

e-mail:sumon.jms@gmaicom

Author $\rho \omega ¥ \S \chi$ : Undergraduate Student, Dept. of Mass Communication and Journalism Comilla University, Cumilla, Bangaldesh.e-mails: asmaislam.mcj@gmail.com,

nobel.mcj@hotmail.com,nhshajib.mcj@gmail.com,

mamun.chowdhury756@gmail.com,rydwanmcj@gmail.com have been coined as " unprecedented" for media (TRT World, 2020).

Media scholars address the role of media in delivering information to the public to protect infectious diseases and in changing behavior, attitude, norms, etc. (Hou, et al., 2018; Dominick, 2009, pp. 434-436). In a study, Schramm (1971) found that mass media played a role in motivating the public about health issues and changing their behaviors (as cited in Piotrow, Kincaid, Rimon \& Rinehart, 1997, p.7). The corona times have deserved more to have these roles of media as people have become more dependent on media ' for seeking out news and programs more ever than before " (TRT World, 2020). Contrarily, fake news and rumors have been "disinfomedic" "that have caused threats to human lives (UN News, 2020a). Thus, media professionals around the world have struggled enough to continue their transmissions and publications following distinctive strategies and health protections to perform these roles and mitigate other challenges. Consequently, journalists have been bound to go outside, talk to people, collect data, and visit offices or hospitals that made them most vulnerable to get exposed to the virus.

Being a new family member of the viruses such as Middle East Respiratory Syndrome (MERS- CoV) and Severe Acute Respiratory Syndrome (SARS-CoV), COVID-19 has emerged in China in December 2019 and then has captured in many countries within very short periods (Sauer, 2020). On March 11, 2020, the World Health Organization (WHO) has declared the COVID-19 outbreak a pandemic. As of 27 May, the virus infected more than five million people, with more than 353 thousand confirmed deaths in 216 countries (WHO, 2020). In Bangladesh, the first case was detected on 8 March 2020. Within a few months, it has erupted in most of the districts infecting 40,321 with 559 confirmed deaths (Institute of Epidemiology, Disease Control and Research [IEDCR], 2020). Because of being a highly contagious character of spreading through droplets of an infected person, maintaining social and physical distances is prescribed among other suggestions, tips and guidelines to prevent the disease (WHO, 2020). However, the job requirements and responsibilities of journalists have not allowed them to follow the prescription always. 
In this backdrop, providing safety measures to journalists has received the highest importance among media scholars, policymakers, and practitioners. Among many others, UNESCO (2020) has urged media organizations to provide training and proper protective materials to journalists. However, most of the journalists have been infected and a few of them have died. While working on this article, no global statistics of journalists infected and died of the virus have been found. Some media reports stated that the virus had captured at least 100 journalists in India as of 4 May 2020 and 54 journalists in Pakistan as of 11 May 2020 (Biswas, 2020; Hashim, 2020).

In Bangladesh, the statistics show a difficult situation. As of 11 May 2020, Bangladesh has ranked third among the most infected countries in South Asia (Maswood, 2020). However, the country grabbed the first position in terms of infections and deaths of journalists in South Asian countries. Nevertheless, a total of 127 journalists had been infected as of 17 May 2020, whereas one death was confirmed among them (Rahman, 2020a). The reports signaled the alarming conditions of journalists in Bangladesh.

Apart from urges from international organizations, there were applications from concerns, practitioners, and media experts to media owners of Bangladesh to provide safety to journalists from the very beginning. Additionally, there was also concern over the negligence of media organizations in providing safety measures to journalists properly (Nabi, 2020).

In this circumstance, this article aimed to examine the management of media employers of Bangladesh in providing safety measures in corona times. The study also focused on its contribution to the journalists' satisfaction, perceptions of infection, and death of journalists in the country, and selfpreparedness in buying safety equipment. This paper also sheds light on comparative analysis between reporters and copy editors to examine the appropriateness of the management system in providing safety measures.

\section{Objectives of the Study}

The present study intends:

- To know the management of media employers in providing safety measures to journalists.

- To measure satisfaction, perception, and selfpreparedness of journalists.

- To examine the effectiveness of media organizations' management in providing safety measures.

\section{ili. Rationale and Significance of the STUDY}

When a few outbreaks like Ebola Virus Diseases (EVD), Zika Virus, and Severe Acute Respiratory
Syndrome (SARS) stroke the world, a bunch of world organizations outlined guidelines and suggestions for journalists to be followed while reporting on crises. However, that didn't encompass the role and responsibility of media employers in providing safety measures to journalists.

Similarly, the literature on outbreaks lacked the issue of safety of journalists since most of them dealt with framing analysis of coverage and the role of journalists and sources (Edimo, 2016, p.76). Very few research works described the safety issues of journalists who covered pandemic or disaster as relevant parts under a wide scope. Those literatures didn't focus on the role of media employers.

Bangladesh has witnessed pandemic for the first time after independence in 1971. Research works on journalism in the corona pandemic were not found during working on this paper. Some of the research works conducted on the safety of journalists of Bangladesh in disaster or others lacked the sole focus on the role of employers.

Corona outbreak has put threats to the lives of journalists (Adriano, 2020). Physical safety has gained high attention in discussions of protections for journalists. It has been urged that media employers should equip journalists with proper and adequate protections. Thus, this paper will add a new knowledge to the field, focusing on the role of employers in providing safety of journalists in times of an outbreak.

The protection of journalists must be a priority to ensure the flow of information to the public at risky times. However, it is always ignored in government and non-government policies. There are no specific safety policies in media organizations in Bangladesh. The findings of the study will be helpful for policymakers, government and non-government agencies, employers, and practitioners to devise comprehensive policies for the safety of journalists in risky times. The study will build a base on which more aspects on the safety of journalists in times of diseases will be explored in the future.

\section{iv. Concept and Context of Safety Measures}

The safety of journalists is contextual that varies from country to country (Hasnan \& Wadud, 2020, p. 27). The issue of journalists ' safety is not new. In the past few years, it became a concern in the media industry (International Women's Media Foundation [IWMF], 2016, p. 2). However, the concerns are mostly related to killing, attack, government interventions, and soon.

Sing \& Goyal (2016) conceptualized safety as protection of "physical, mental, spiritual, social, financial, political, emotional, psychological, educational...or any other event which could be nondesirable' (p. 425). 
Because of the job requirements and responsibilities, journalists are bound to have first responses to react to the crisis and disasters that made them potentials to be infected or affected (Brayne, 2007, p.1, 11; Steffens et al., 2012, p.2). According to scholars and practitioners, physical safety should be prioritized in these contexts.

Thus, providing necessary materials including personal protective equipment (PPE) to journalists to cover disasters are prescribed (Skliarov Kaptan \& Manesh, et al., 2017; Moore \& Lakha, 2002, pp. 511). Potter \& Ricchiardi (2009) prescribed hand sanitizer, wipes, safety equipment, and so on while covering traumatic incidents (pp.13-25).) While covering epidemic, Reporters Without Borders and UNESCO (1992) focused on wearing long-sleeved clothes to prevent mosquito bites and direct contact with a sick person (p.55).

In the corona pandemic, Unicef (2020) recommended 17 guidelines. The Committee to Protect Journalists (CPJ) summarized tips given by the Global Investigative Journalism Network into five measures (GIJN, 2020, para. 1). International Journalists` Network outlined ten tips. If summarized all of the tips and guidelines of scholars and suggestions, two types of safety measures can be provided by media employers in corona times. Those are safety equipment and a safe atmosphere. Equipment included masks, sanitizers, gloves, and PPE. On the other hand, a safe atmosphere encompassed the opportunity of working at home and hygiene inside the office.

In Bangladesh contexts, transport facilities and timely payment of salary have been considered as safety issues in corona times. All of private and public transports were shut down due to lock-down as directed by the government. Haider (2014) argued that most media organizations run industry with irregular payments month after month (p. 340). Despite legal obligations on timely payment (Bangladesh Labor Act, 2006, Amendment 2013), salary, and festival bonus on the occasion of Eid-Ul-Fitr, a religious festival of Muslims were also a concern in corona times. On 16 April 2020, the Dhaka Journalists Association expressed deep concern and urged the employers of the respective media organizations to pay unpaid salary and other facilities (Inqilab, 2020). The study, thus, included transport facility in a safe atmosphere and timely salary and bonus into economic safety.

From the context of Bangladesh, the overall focus of the paper will be on three types of safety measures: Safety Equipment, Economic Safety, and a Safe Atmosphere to see to what extent, and how these measures have been provided to journalists.

There is no specific scheme for the payment of salaries and bonuses on TV channels in Bangladesh. These are decided by different policies of the channels
(Swapan, 2017). The bonus procedure of both newspapers and TV varies organization to organization.

In light of the provisions of the Bangladesh Labor Act, 2006, Bangladesh government established the general payment scheme named 'the $8^{\text {th }}$ wage board ' in 2013 for the journalists of newspapers.

\section{Research Questions}

This paper will deal with some questions given below:

1. To what extent media employers have provided safety equipment, economical safety, and a safe atmosphere to their respective journalists in corona times?

2. To what extent the management of employers in providing safety measures have gained the satisfaction of journalists?

3. To what extent the management of employers have contributed to journalists' self- preparedness in buying equipment and their perception about the infection and death of journalists?

\section{Literature Review}

Thomas and Senkpeni (2020) examined the journalism practice during the 2013-2016 Ebola pandemic in Liberia. Results revealed that local journalists suffered from the scarcity of safety equipment and sufficient salary while visiting the infected regions to report the outbreak (Thomas \& Senkpeni, 2020, p.57). Edimo (2016), in his master's thesis, interviewed 20 African journalists who covered the 2014 Ebola outbreak and found that lack of material resources such as Personal Protective Equipment (PPE), transports, etc. contributed negatively to the coverage of outbreak (p.69).

Besides, the lack of financial and transport supports worked as obstacles to cover the issue (Edimo, 2016, p.72). Contrarily, Boasiako (2017) states in his dissertation for Doctor of Philosophy that journalists in Ghana and Sierra Leone used innovative precautionary measures to stay safe and distinctive methods to cover the emerging 2014 Ebola outbreak (p.195). Hooker, King \& Leask (2011) conducted a survey on 16 journalists from Australian media organizations reporting on avian influenza and pandemic planning to understand the journalists ' views (p.224). Findings revealed that journalists felt the importance of freedom while working on influenza (Hooker, et al., 2011, p. 224).

Epidemic or pandemic is considered a biological disaster while The United Nations Office for Disaster Risk Reduction classified it as a visible disaster (Skliarov et al., 2017, pp.18-19). After interviewing 46 Nepali journalists who covered natural disasters in Nepal, Sreedharan, Thorsena and Sharma (2019) identified that lack of preparation, and proper plan by 
the employers in disaster times hampered 'journalism practice, journalism strategy, and journalistic identity ' ( $p .11)$. The literature lacked the sole focus on the role of media organizations in providing safety measures while covering outbreaks or disasters.

Jamil (2019) conducted a study on the safety of journalists in Pakistan. Results revealed that the weakness of the legal and judicial systems of Pakistan was responsible for impunity, which was enhancing the risks and life threats to journalists (Jamil, 2019, p. 64). Jamil (2019) observed that "correlated systems" of the state and their effective interactions can ensure the safety of journalists (p.53). Similarly, Murthy (2018) identified the failure of the central and state governments of India in providing proper safety to journalists (p. 146). In a survey study on 200 journalists, Olorunda (2019) found the negligence of the government in offering due protection to journalists while covering the election in Southeast Nigeria.

In Bangladesh, Akhter and Ullah (2014) conducted a study on 23 local journalists who covered cyclones, and found that all of the respondents suffered from the negligence of employers (p.6). The results of this study revealed that journalists experienced the lack of safety equipment, incentives, and proper recognition from respective houses that made them bound to take safety measures themselves for personal and professional protections (Akhter \& Ullah, 2014, p. 8). However, the study didn't focus on safety plans and guidelines for journalists on behalf of their respective offices.

In a study on job stress, Huda and Kalam (2015a) found that among the lack of other facilities, TV journalists of Bangladesh suffered from inadequate supports from their employers (p. 86). However, in another study Huda (2018b) found that newspaper journalists didn't consider the lack of supports as a factor for job stress (p.143). In a study on safety of journalists of Bangladesh, Hasan and Wadud (2020) found that the "censorship machine" on journalists created negative public perception about the trustworthiness of news (p.33). The result of this study showed that "...for Bangladeshi journalists, safety encompasses job security, self-censorship, avoiding bodily harm (imprisonment, enforced disappearance, and so forth), avoiding harassment, and opting for agenda promotion of the government" (Hasan \& Wadud, 2020, p. 33).

\section{Vil. Theoretical Discussion}

As media organizations deal with employees, business, manufacturing, distribution, etc., the application of organizational and management theories becomes a tool to analyze the media management system. These theories are used to focus on various issues, including responsibilities of media managers to employees, factors that influence psychology, and behavior, interrelationships among all parts of media organizations, and so on. Despite differences between media organizations and other organizations in terms of production, distribution, etc. the theories become the basis of a theoretical and conceptual framework to understand unknown and less known aspects of mass communication and social science research (Mierzjewska \& Hollifield, 2006, p, 37-38).

Administrative Management Theory: The theory developed by French Engineer Henry Fayol (1841-1925) focuses on the ways by which a complex organization can make its structure and guidelines to enhance workers' capabilities and skills. According to Akrani (2011), Fayol emphasized six categories of activities, including security that an organization must acquire to reach its goal. Other activities are technical, commercial, managerial, financial, and accounting.

Based on the foundation of this concept, Fayol described 14 principles that can bring success to the organization through its proper application. Those are Division of Labor, Authority, Discipline inside the organization, Unity of Command, Unity of Direction, Subordination of individual to a common goal, Remuneration (Financial/Non-Financial) such as wage, bonus, awards, etc. for employees satisfaction, Centralization, Scalar Chain (Single Uninterrupted line of authority), Order, Equity (Friendly and fair to the employee), Stability of Personnel, Initiative (Freedom to subordinate) and Espirit de Corps (Team Spirit and Unity) (Kwok, 2014, p.31).

Human Relations Theory: The theory developed by Elton Mayo (1880-1949) focused on people's psychology and behavior rather than the sole emphasis on production. The management of an organization needs to create a conducive environment for working together to achieve the objectives through effective and efficient activities of the people (Godwin, Handsome, Ayomide, Enobong \& Johnson, 2017, p. 78).

From this perspective, Human Relations Theory emphasized on people to consider them as "human being " rather than a machine (Chand, 2017 as cited in Tirintetaake, 2017). Thus, one of the factors that influences the behavior of employees has been resolved within an organization.

Kwok (2014) explained that employees are motivated by social needs rather than economic needs, according to the Human Relations Theory. To understand employee's unique needs and satisfy their social needs, managers should focus on relationships, harmony, psychology, behavior, etc. of an employee for efficient production (Kwok, 2014, p. 34).

\section{Vili. Research Methodology}

The research area of the study is Dhaka, the capital city of Bangladesh since it has been the most 
infected city in Bangladesh [IEDCR, 2020]. Most of the journalists infected by the virus work in Dhaka. (Rahman, 2020a).

According to the Information Ministry of Bangladesh, there are 214 daily newspapers and 28 private TV channels in Dhaka. Based on Random sampling, the study involved 24 media where there are 12 daily newspapers and 12 TV channels. The study incorporated 48 journalists by selecting one reporter and one copy editor from each media for comparative analysis. Newspapers and TV channels are "'identified as setting the agenda for public discussion ' ' (Hooker et al., 2011, p.224). Thus the study excluded other media. For the completion within the time, the study focused on two journalists from each media. All of the selected journalists had three to fifteen years of working experience in media. They were known to have reported on the corona pandemic.

Since the results of corona disease suggested that the rate of transmission of the virus is higher in older adults, media organizations of Bangladesh outlets have deployed more young journalists to cover the pandemic to skip the risk. So, the age limit of selected journalists was 25-40. Among 48 participants, there are 40 males and the rest are females. However, the study avoided gender perspectives as it aimed to focus on a holistic approach to safety issues and comparative analysis between reporters and copy editors.

The reporter included staff reporter, senior reporter, and special correspondent, whereas copy editor encompassed sub-editor, newsroom editor, deputy news editor, and news editor. For privacy, the paper did not mention their names.

Methods of Data Collection and Analysis: The study employed a survey method to collect data. To do that, a structured questionnaire consisting of 15 open and close-ended questions were created based on the research questions. The data were collected from 1 May 2020 to 25 May 2020.

The study employed both quantitative and qualitative methods to analyze the data. Though data is quantitative, elaborate answers by some of the journalists to some questions needed to be analyzed qualitatively. The data have been presented in graphs, pie charts, etc. using infographic software.

\section{Analysis of the Survey}

To complete the survey, 35 journalists answered the questionnaire through the mail and the rest, via cell phone. The questionnaire was elaborately described when journalists faced difficulties to understand the questionnaire. Every journalist answered all of the questions. Without the 'yes-no' questions and questions on economic safety and satisfaction, every question had options for giving more than one answer and put other comments.

Getting Safety Measures: The participants were asked whether their employers provided safety measures to them. The Majority of the participants (96\%, 46 among 48) replied affirmatively, and the rest (4\%, two among 48) negatively (Figure 1). The study scrutinized the affirmative answers in terms of safety equipment, safe atmosphere, and economic safety. All of those who replied negatively mentioned two reasons: negligence of their organizations and the financial crisis of office.

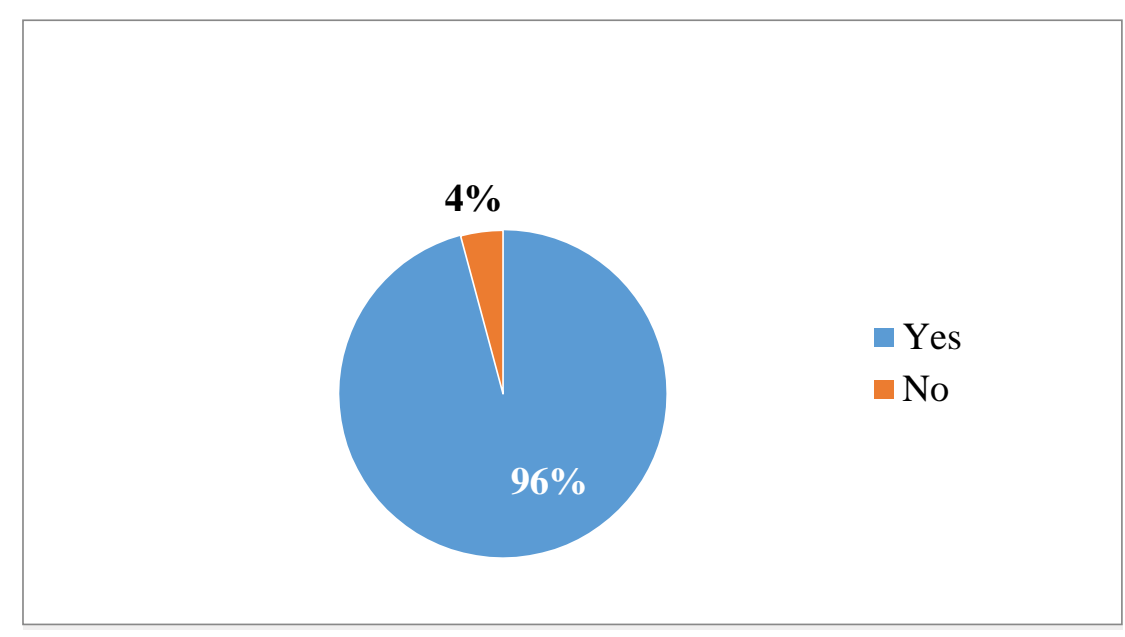

Figure 1: Responses of Getting Safety Measures Provided by Office.

Getting Safety Equipment: The participants were asked what types of safety equipment they received from their respective houses. The majority of participants (73\%) got masks and sanitizers.37\% said that they received PPE, while 29\% got gloves (Figure: 2). 


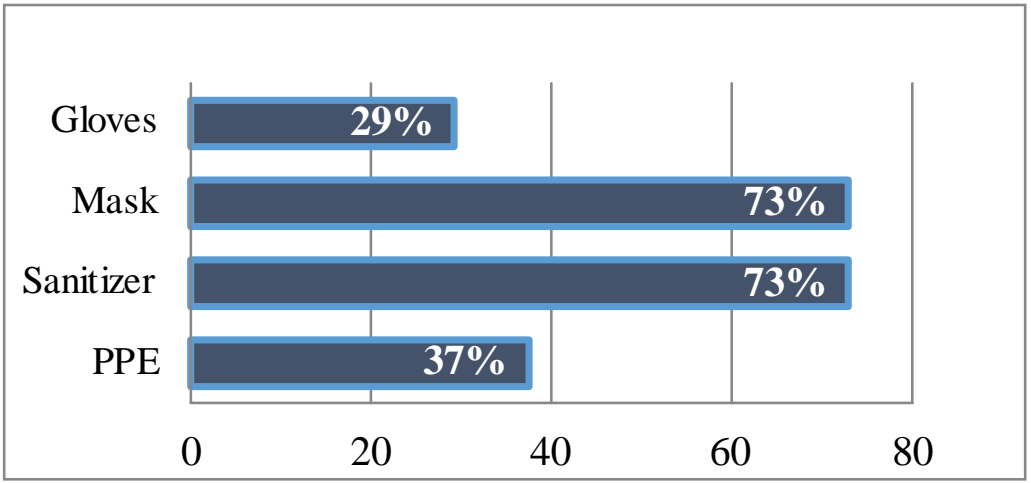

Figure 2: Safety Equipment

Safe Atmosphere: The majority of the participants $(100 \%)$ said that their organizations emphasized highly on maintaining safety inside the office by setting sanitizing, temperature measurement systems, distancing among desks, and decreasing the number of employees at the office. In comparison, 69\% said that they got the opportunity to work at home. TV journalists had less opportunity to work at home. 92\% said that they had transport facilities form office (Figure 3).
However, each of them said that despite transport facilities, it was quite difficult to maintain social distancing there. When asked, $77 \%$ said that their transports were under regular sanitizations.15\% said that transports were not being sanitized regularly while $5 \%$ of participants said that they didn't know about it. $4 \%$ said that they made drivers sanitize transport very often. Two journalists said that they had their private transports and didn't need office transports.

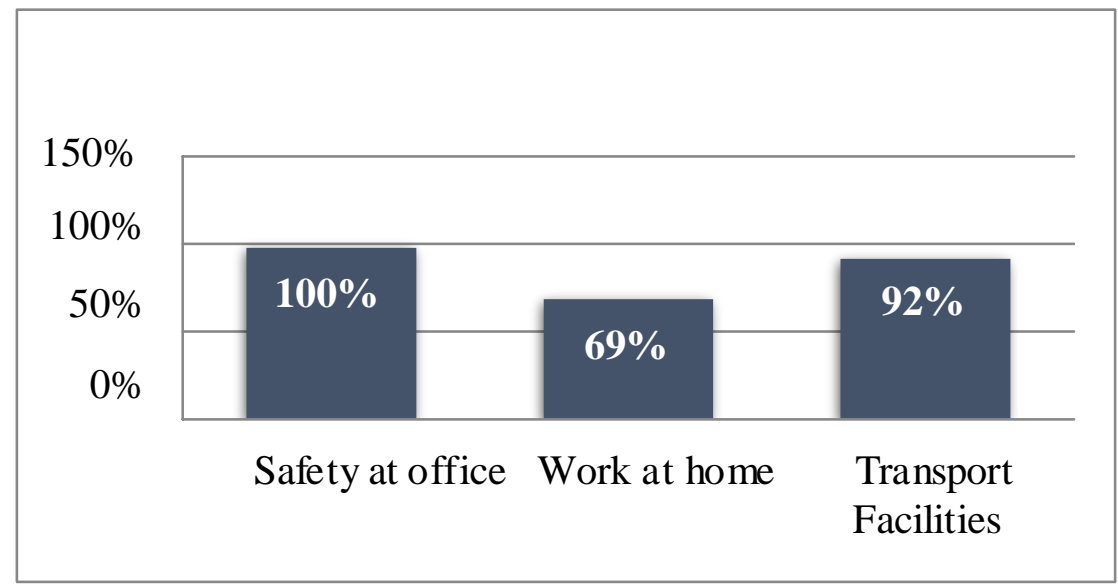

Figure 3: Safe Atmosphere

Economic Safety: The system of payment of salary and bonus of newspapers and TV channels has been mentioned earlier. Though there was concern regarding regular payment procedures of the organization, the majority of the journalists (75\%) said that they got salary regularly in corona times while 25\% replied that they didn't get salary regularly (Figure 4).

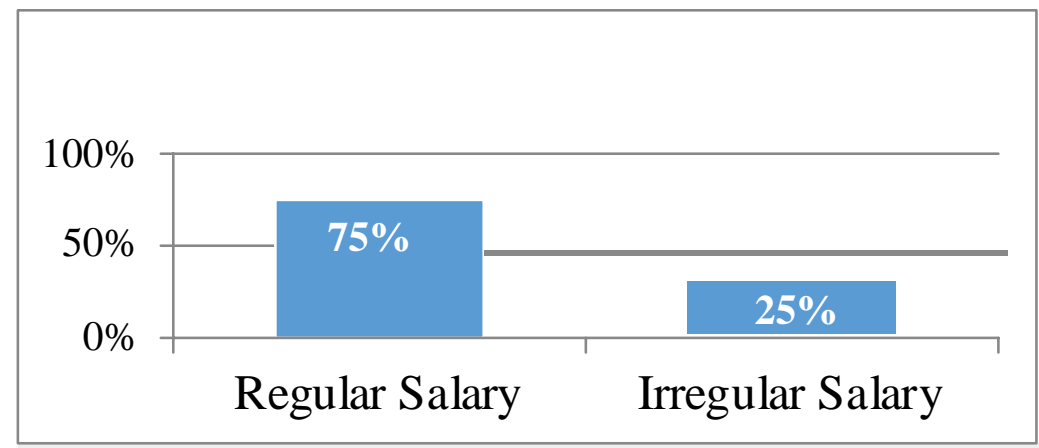

Figure 4: Economic Safety 
Contrarily, most of the journalists suffered from cut off and no bonus ahead of the Eid-festival, 2020 (29\% for each). $42 \%$ of journalists said that they got a full bonus (Figure 5). In the total calculation of the responses of 48 journalists, the study found that $31 \%$
(15 among 48) journalists got regular salary and full bonus. In contrast, 69\% (33 among 48) who got regular or irregular salary suffered from cut off or no bonus. To clarify more, $10 \%$ (5 among 48) suffered from irregular salary and no bonus (Figure 6).

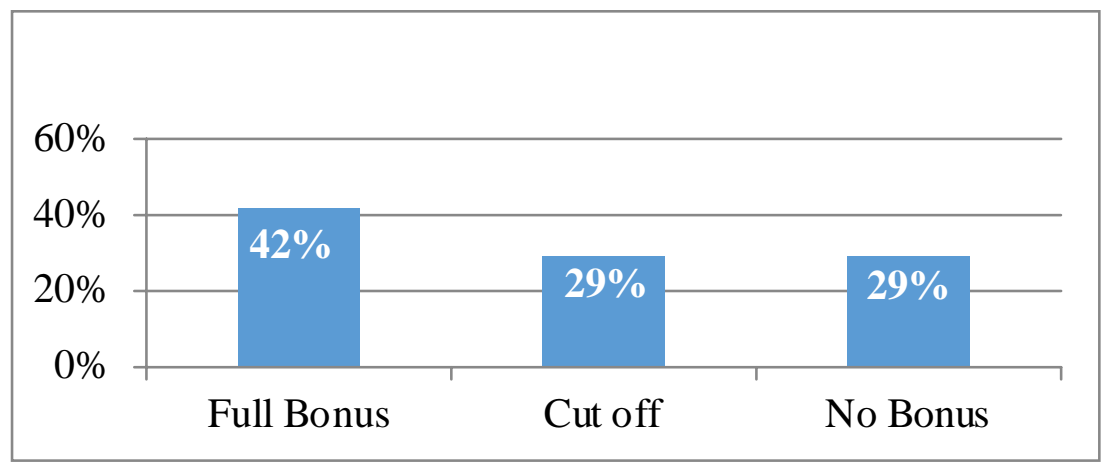

Figure 5: Bonus System

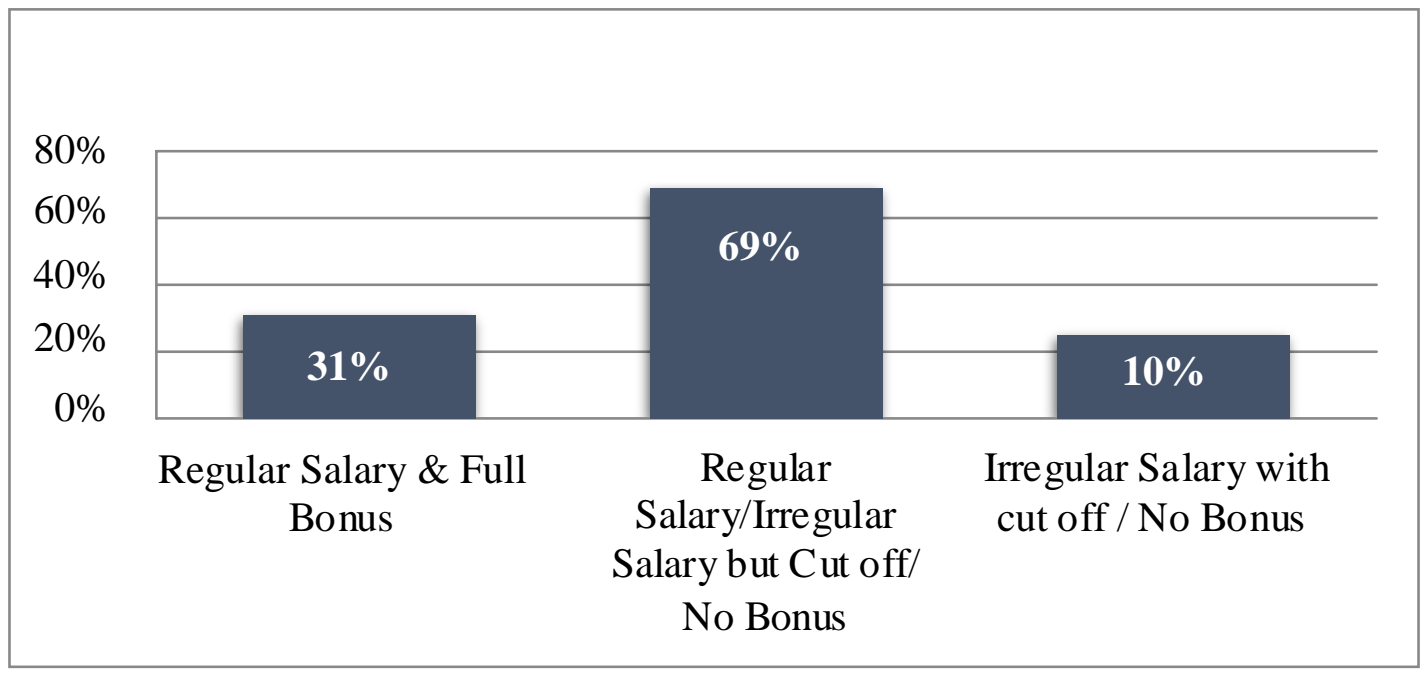

Figure 6: Salary \& Bonus

Satisfaction and Dissatisfaction: The Participants were asked regarding their satisfaction with safety measures provided by the office. The majority of the participants
$(60 \%, 29$ out of 48 ) replied affirmatively while $40 \%$ (17 among 48) said that they were dissatisfied (Figure 7).

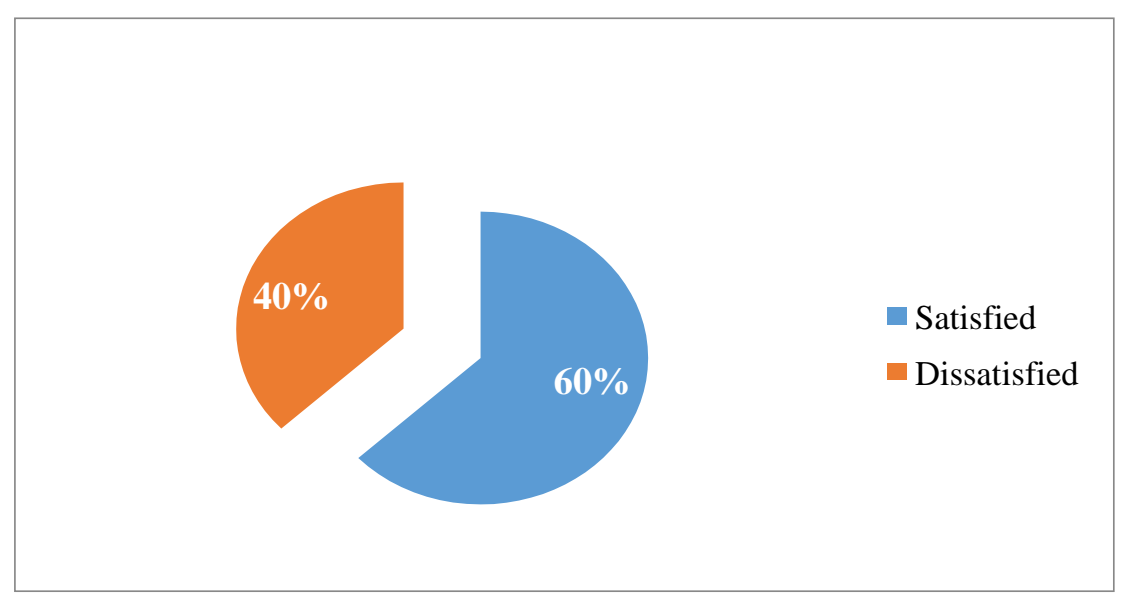

Figure 7: Satisfaction of Journalists 
However, the study found a low level of satisfaction in the majority of participants (35\%, 17 among 48) while $25 \%$ (12 among 48) said that they were highly satisfied with safety measures provided by office (Figure 8). Participants answered elaborately regarding their high and low satisfactions. Highly satisfied participants said their offices were better than other organizations in providing safety measures. One journalist said that his employer did all of the necessary things for them, even tried to rent a hotel for their respective employee to stay in corona times. According to low satisfied participants, the safety measures provided by their organizations were non-standard, irregular, improper, and inadequate. Some equipment, particularly PPE, was usable for one time. Three Journalists of two organizations mentioned that their office provided the safety equipment which they got as gifts from a third party. One journalist said that he was low satisfied with safety measures but dissatisfied with the working systems of his office. The system didn't allow them to maintain social distancing and follow other protocols.

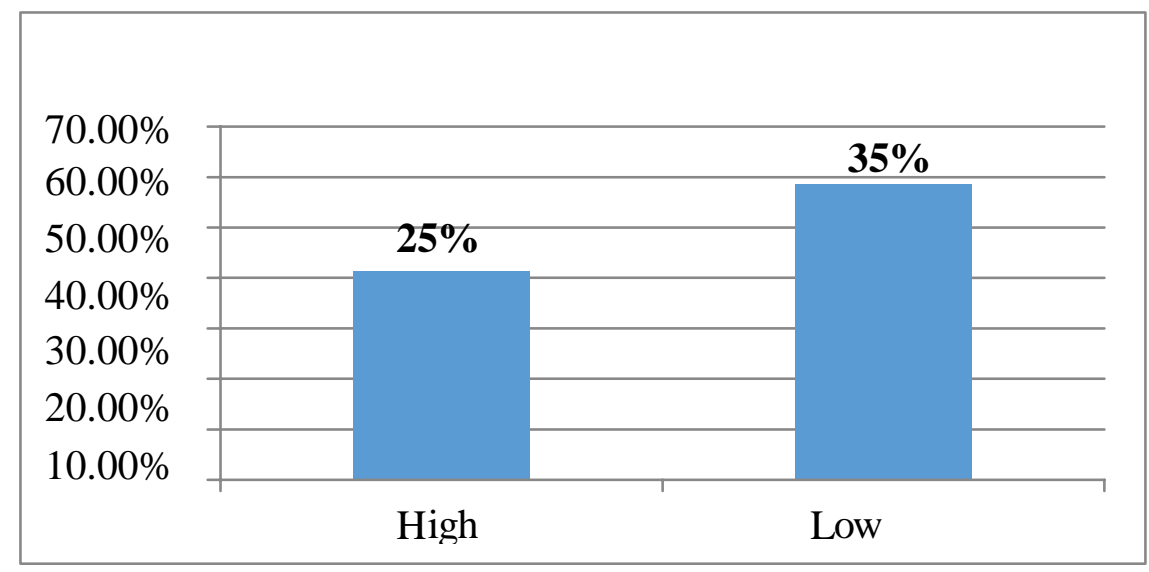

Figure 8: Level of Satisfaction

On the other hand, the dissatisfied participants were asked to tell the causes of their dissatisfaction. The majority of participants (94\%) pointed out inadequate safety measures as the reason behind their dissatisfaction. $65 \%$ of participants told about irregular providing, while $35 \%$ mentioned inappropriate safety measures (Figure 9).

Self-Preparedness: The majority of the participants had to buy masks (81\%) and then sanitizer (68\%). 49\% bought gloves, while $8 \%$ bought PPE and $22 \%$, others (Figure 10). The responses came while they were asked whether they bought safety equipment. According to responses, $73 \%$ (35 among 48) bought safety equipment while 23\% (11 among 48) bought nothing. 4\% (2 participants) said that they didn't buy, but collected form some journalists associations. The majority of the respondents who bought safety equipment gave elaborate answers. $45 \%$ of participants said that they bought because of improper, irregular, non-standard, and inadequate safety equipment provided by the office. $15 \%$ said that they bought for family and personal usage since the first detection while $6 \%$ bought for extra safety. $7 \%$ didn't give any answer.

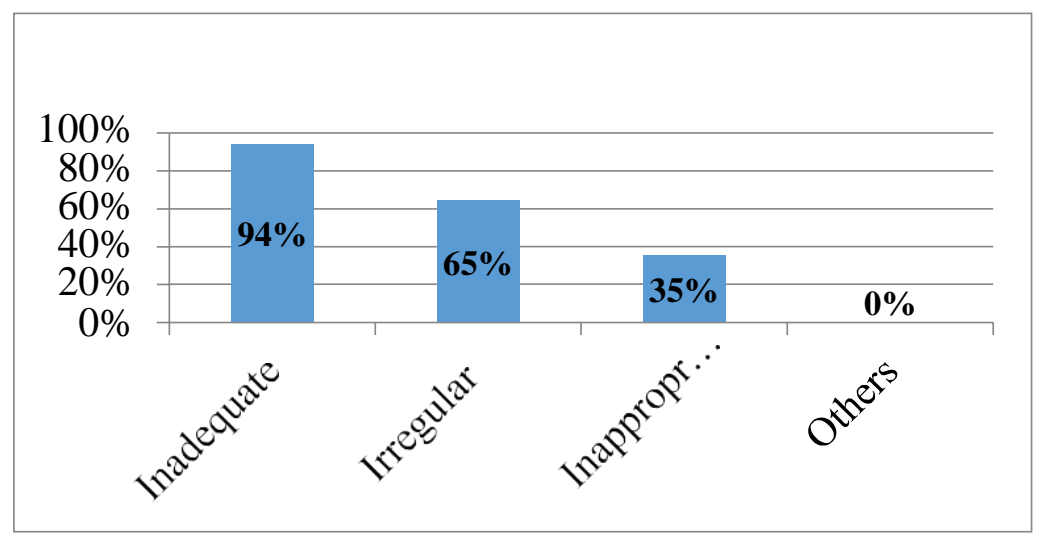

Figure 9: Causes of Dissatisfaction 


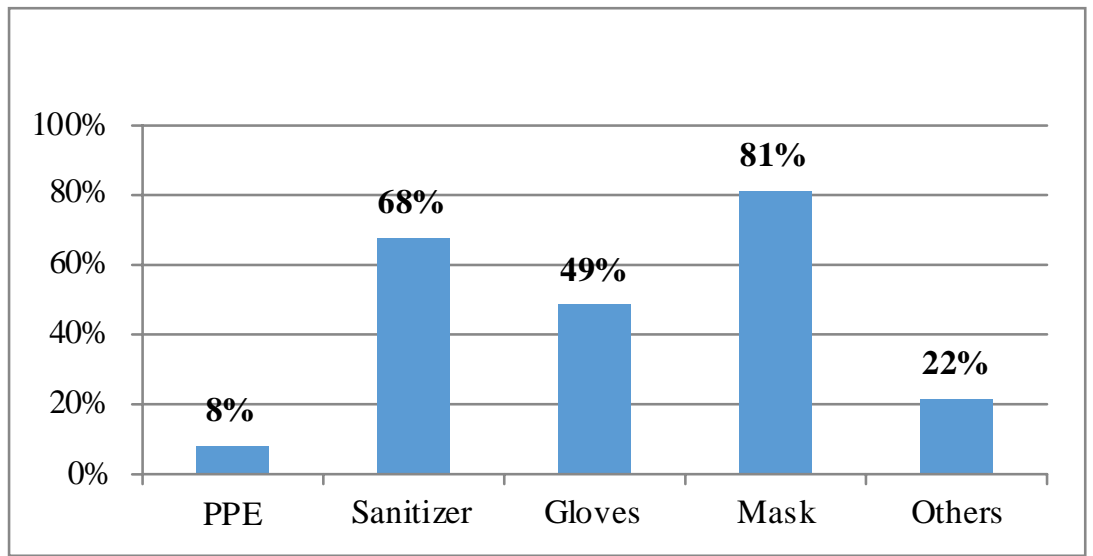

Figure 10: Self-Preparedness of Journalists

Perception about the Infection and Death of Journalists: The participants were asked whether they would think that inadequate and inappropriate safety measures of media organizations were responsible for the infection and death of journalists in the country. A large number of participants (90\%) replied affirmatively, while a few
(10\%) negatively (Figure11). Highly satisfied participants (Figure 8) rationalized their affirmative answers about the perception that other media organizations didn't provide proper safety measures to their journalists as their employers did.

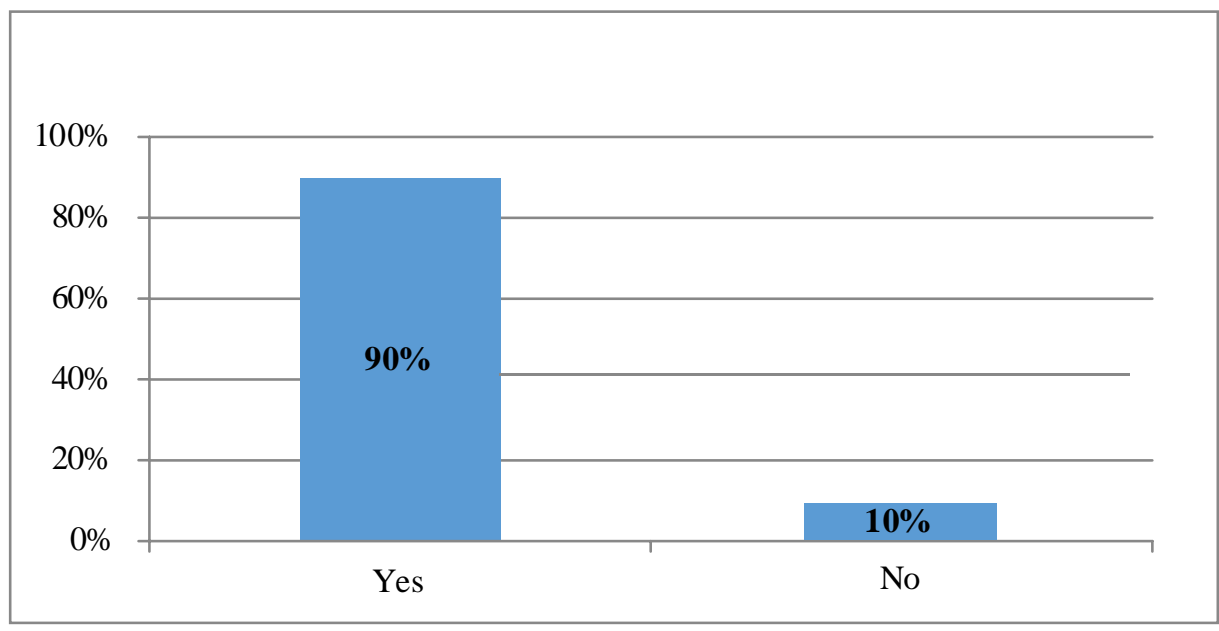

Figure 11: Perception of Journalists

a) Comparative Analysis

Responses of participants revealed that media organizations could not maintain equal distribution in providing safety measures between reporters and copy editors. Providing safety equipment to reporters (24 participants) and copy editors (24 participants) was not equivalent. Among the copy editors, only $4 \%$ got PPE. Inequality was reflected in providing gloves. $45 \%$ of reporters said that they got gloves while only $16 \%$ of copy editors got gloves. However, the frequency of distributing masks and sanitizers is almost close to each other (Figure 12). 


\section{Reporter \& Copy Editor}

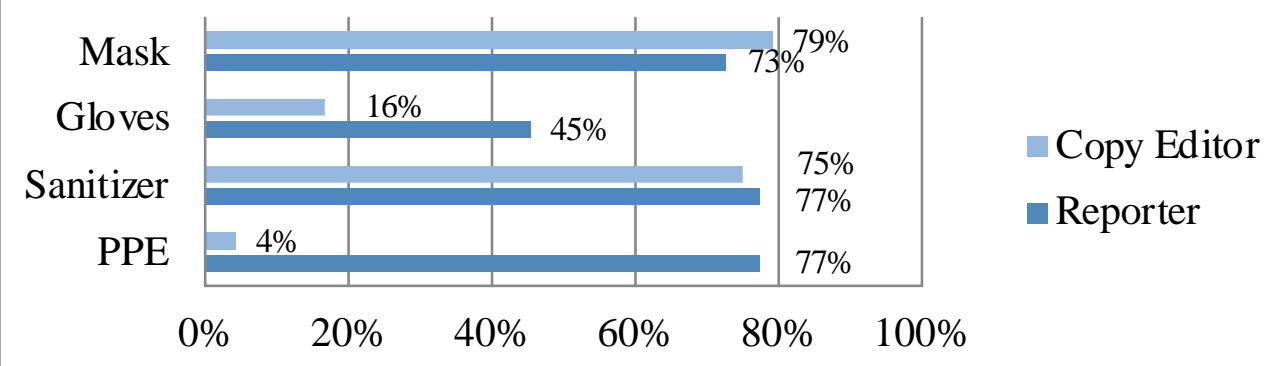

Figure 12: Safety Equipment

Simultaneously, reporters got more equal transport facilities (92\%). 96\% reporters and opportunities to work at home than copy editors. $83 \% \quad$ 100\% copy editors said that their respective offices set reporters got this opportunity while $54 \%$ copy editors got safety protocols at the entrance of and inside the office it. Copy editors said that they needed to visit the office very often. Both the reporter and the copy editors got (Figure13).

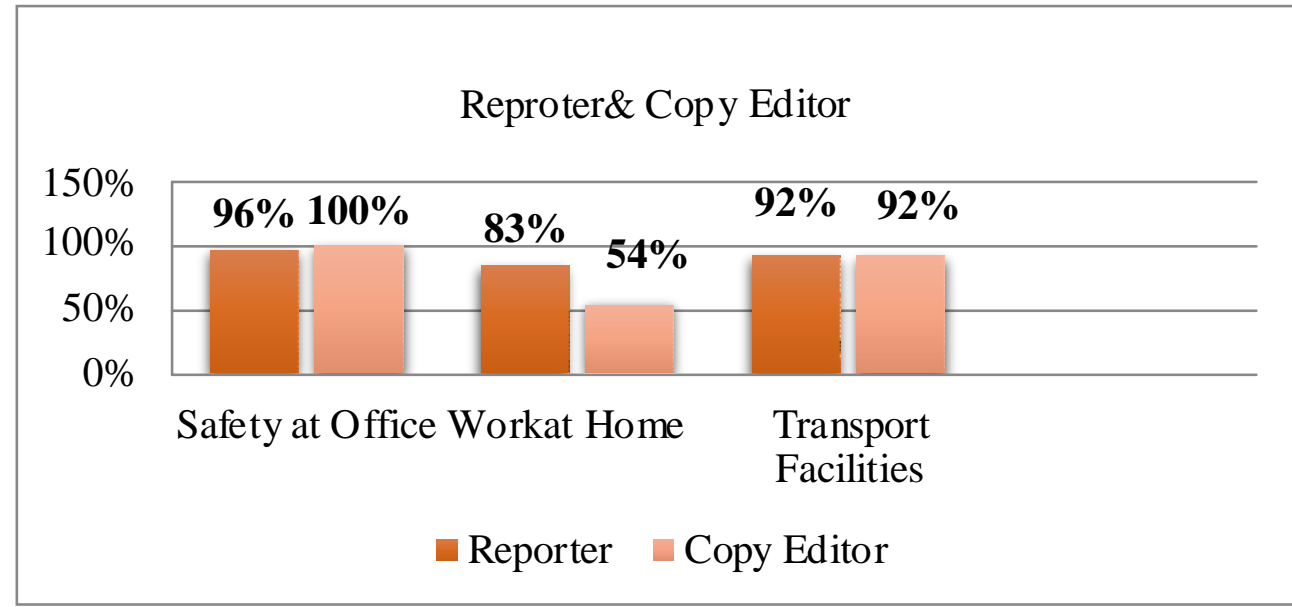

Figure 13: Safe Atmosphere

Reporters and copy editors were asked about getting a salary. $75 \%$ of both reporters and copy editors got salary timely while $25 \%$ of both of them didn't get the salary. However, the distribution of salary and bonus between reporter and copy editor depends on how the respective organizations take initiatives of payment. Sixteen media organizations (7 newspapers and 9 TV) paid regular salaries to both reporters and copy editors. Journalists of 4 media (3 newspapers and 1 TV) didn't get the salary. But two reporters of two media organizations (1 newspaper and 1 TV) and two copy editors of another two media organizations (1 newspaper and 1 TV) said that they didn't get the salary regularly in corona times (Figure 14). 


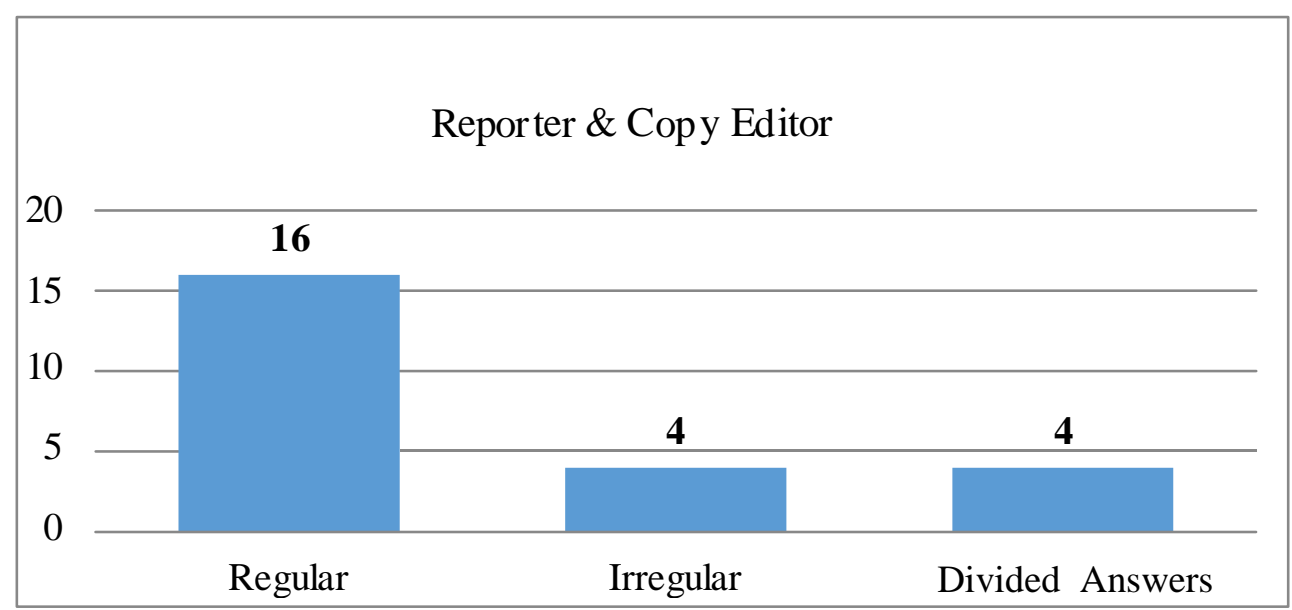

Figure 14: Economic Safety

According to data given by participants, among selected organizations, 12 Media (6 Newspapers and 6 TV) pay bonus equal to basic salary, five media (3 Newspapers and 2 TV) pay $50 \%$ of gross salary, two media (1 Newspaper and $1 \mathrm{TV}$ ) pay $60 \%$ of basic salary. Two TV pay $60 \%$ of gross salary, and another TV pays $50 \%$ of basic salary. Two newspapers pay double of basic salary. Figure- 9 indicates that including these two newspapers, seven media (5 newspapers and 2 TV) cut off bonus from $25 \%$ to $50 \%$ whereas seven media (4 newspapers and 3 TV) didn't pay bonus at all. 10 media (3 newspapers and $7 \mathrm{TV}$ ) paid a full bonus to the participants (Figure 15). Here, the distribution of bonuses between reporters, and copy editors was dependent on initiatives of respective organizations.

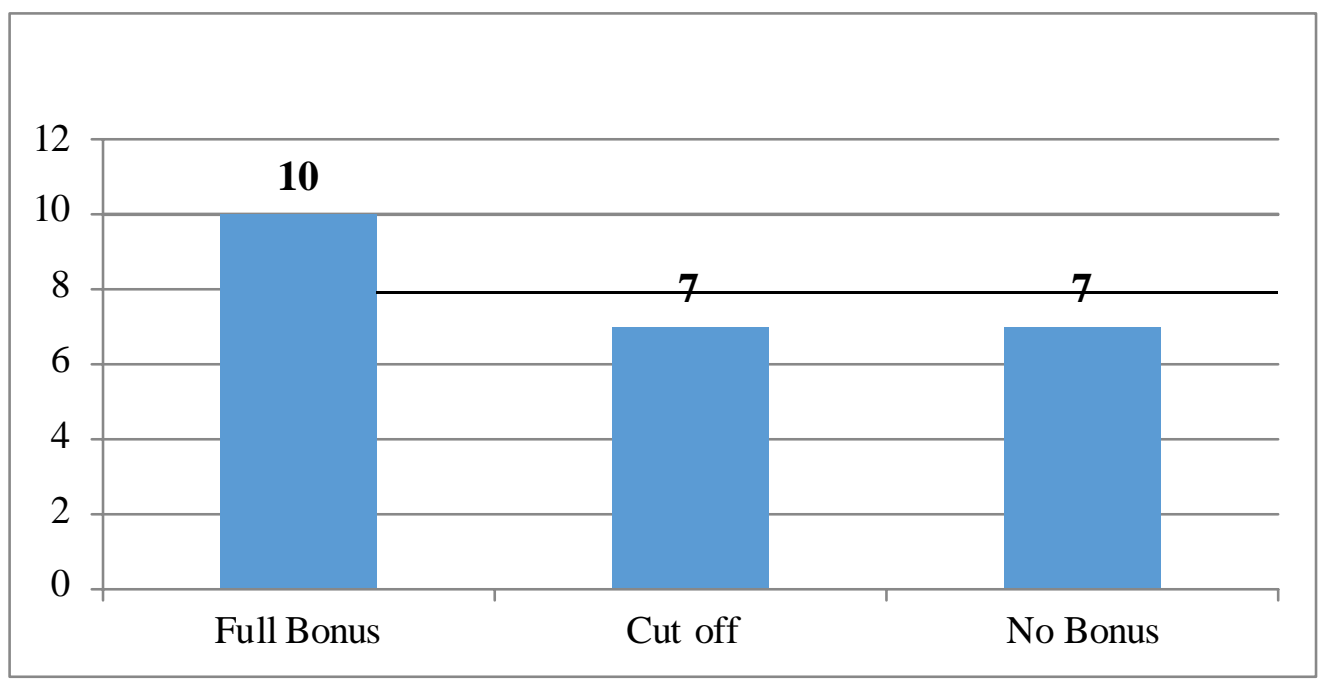

Figure 15: Bonus: Reporter \& Copy Editor

In terms of satisfaction, dissatisfaction and level of satisfaction, the data shows that the satisfaction of reporters (73\%) is higher than copy editors (54\%). The dissatisfaction of copy editors is higher than the reporter (Figure 16).

High and low satisfaction of reporters is equal $(36.40 \%)$, while copy editors differed. The satisfaction of $17 \%$ copy editors is high while $37 \%$ is low (Figure 17). 


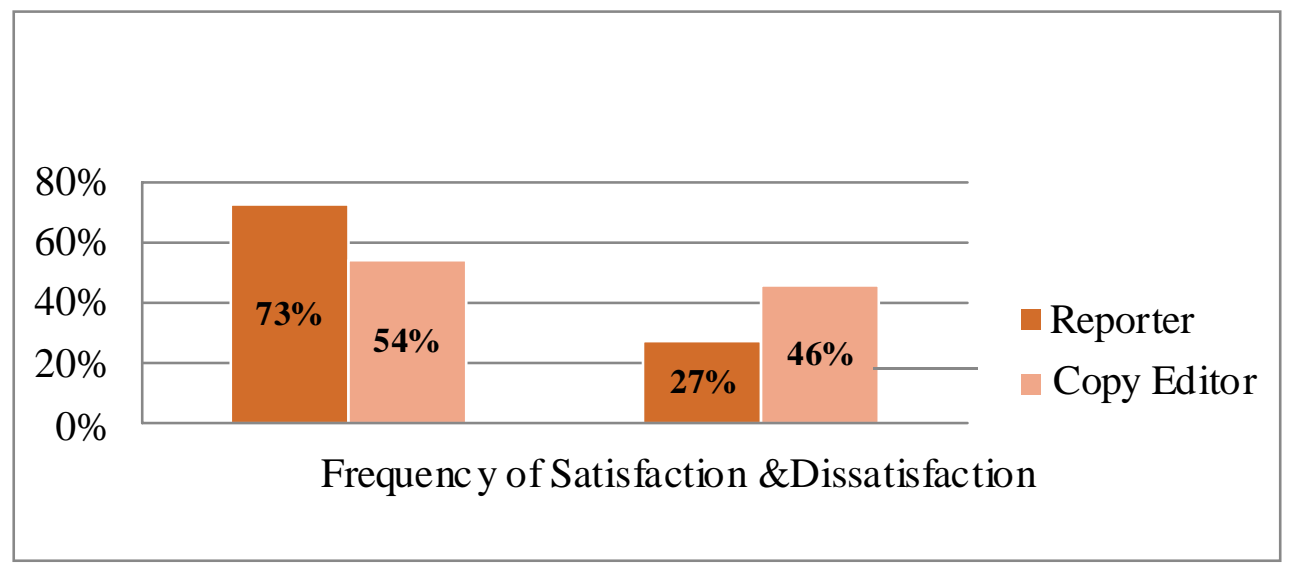

Figure 16: Satisfaction \& Dissatisfaction

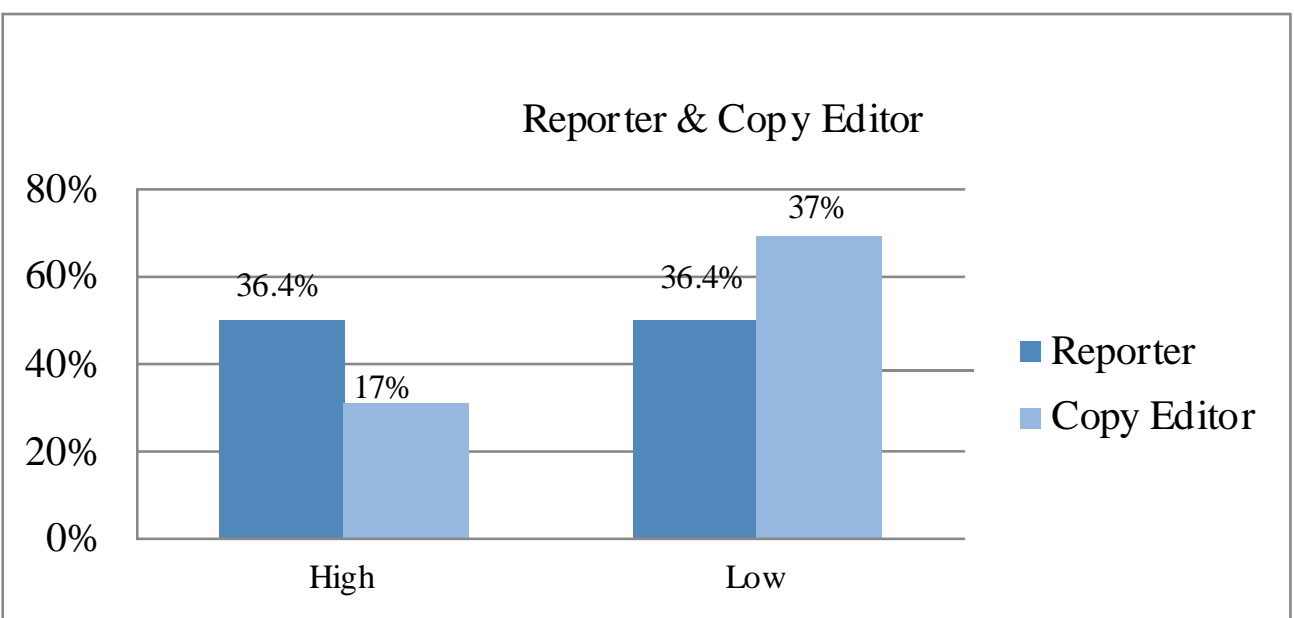

Figure 17: Level of Satisfaction

In comparison between the reporter and copy editors bought the masks, 37\% reporters and $61 \%$ copy editor, a large number of reporters bought more safety equipment than copy editors. $15 \%$ reporters and $11 \%$ copy editor bought PPE, 79\% reporters and 55\% copy editors bought sanitizers, $84 \%$ reporters and $78 \%$ copy editors bought golves, and $21 \%$ reporters and $17 \%$ copy editors bought others (Figure 18). The data show the trend of buying safety equipment is higher in reporters than in copy editors.

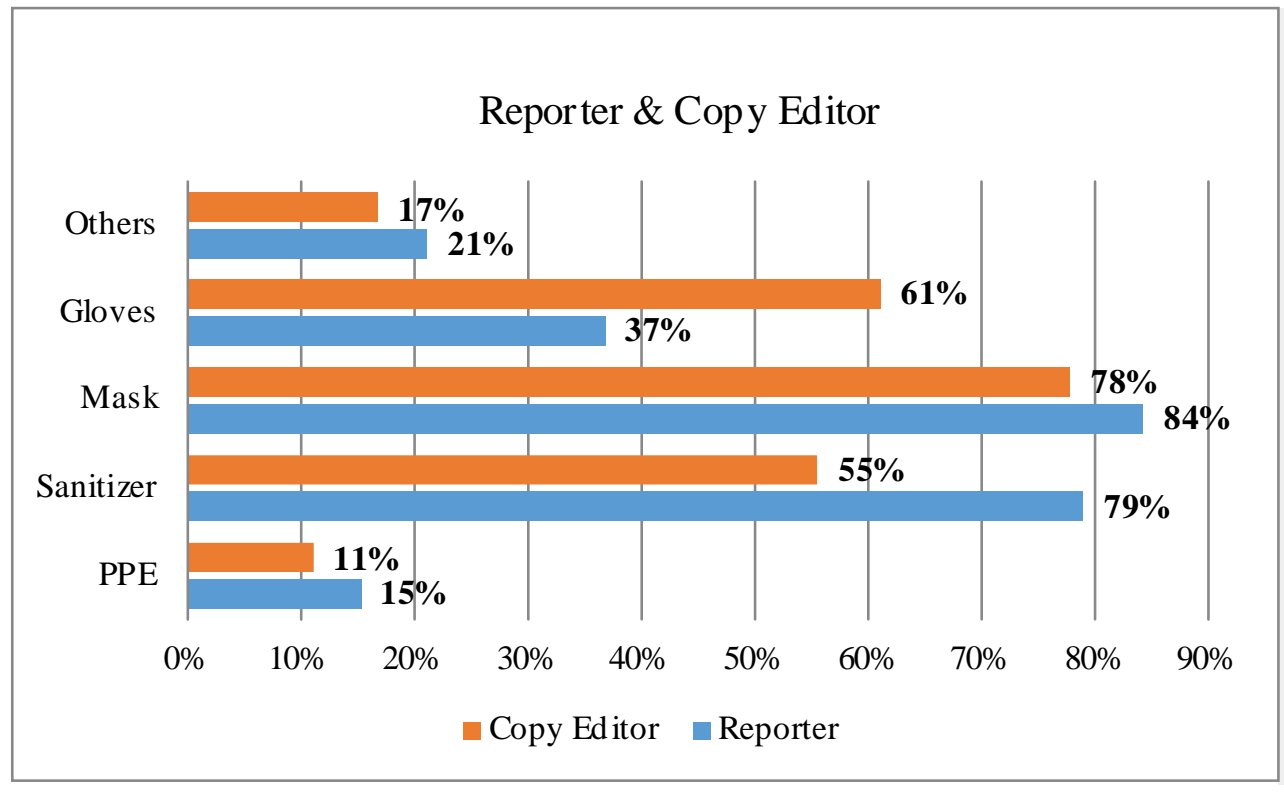

Figure 18: Self-Preparedness 
Perception about the infection and death of journalists differed between reporter and copy editors. More than reporters, 96\% copy editors think that lack of proper and adequate safety measures are responsible for the infection and death of journalists in the country. In comparison, $83 \%$ reporters gave the same opinion. $17 \%$ reporters and $4 \%$ copy editors replied negatively (Figure19).

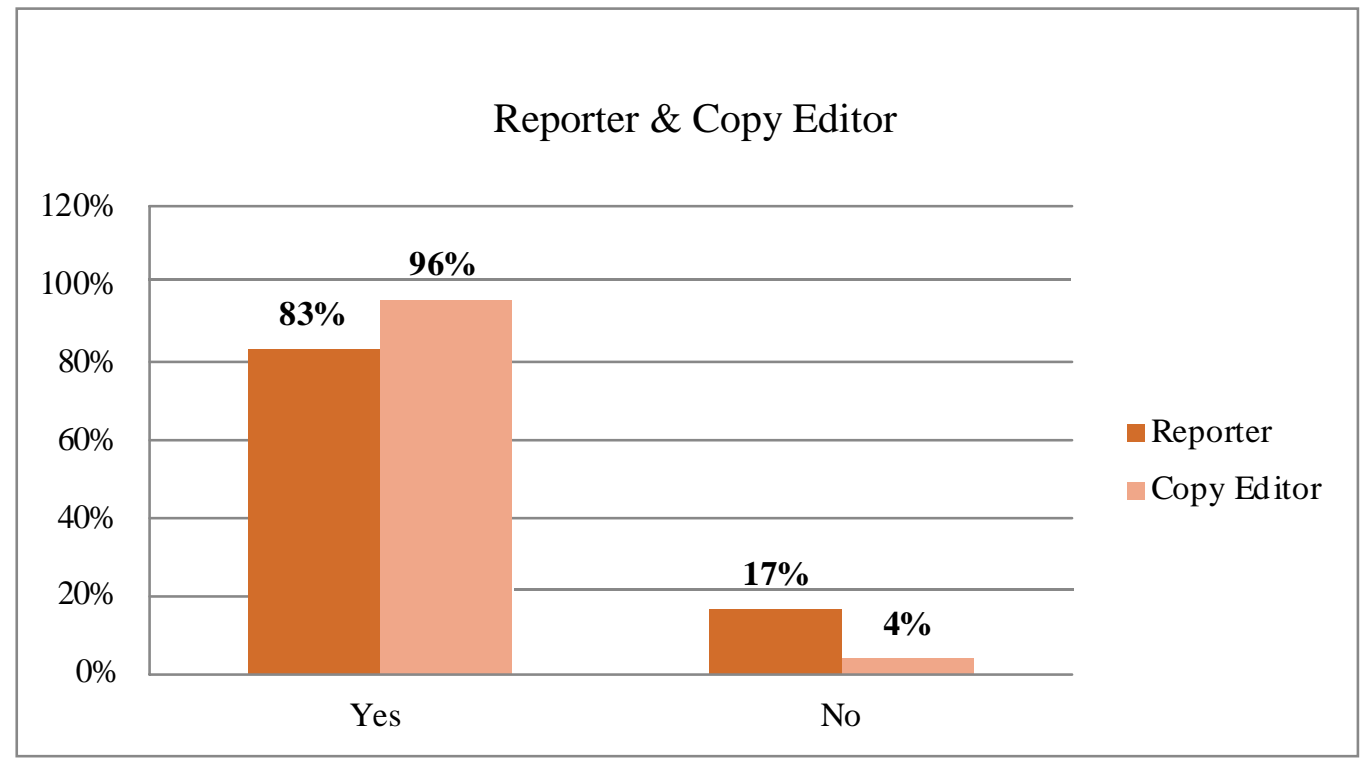

Figure 19: Perception

\section{Result and Discussion}

Based on the responses of the majority of participants, the study revealed three findings. One of them is improper, imbalanced, inadequate, nonstandard and irregular safety measures that have been provided to journalists by their employers, the second finding is the unequal and distribution of safety measures between reporters and copy editors, and the last one is that such mode of employers contributed largely to satisfaction, perception, and selfpreparedness of journalists.

The objective of the study that the first research question dealt with in this study was to examine the mode of employers in providing safety measures. The study revealed that though the majority of journalists (96\%) got safety measures, employers could not make an equal and proper balance among safety equipment, economical safety, and a safe atmosphere provided to journalists. Journalists got less PPE and gloves (Figure2). According to the majority of responses, employers have taken good initiatives to provide a safe atmosphere (Figure 3) though it differed between reporters and copy editors (Figure 13). The majority of journalists suffered from an economic crisis. A few of them got regular salary and full bonus while the majority suffered from irregular or cut off or no bonus (Figure 6). Thus, the results of getting safety measures and satisfaction differed (Figure 6) that the second research question dealt with. The study shows that more than two-thirds of participants suffered from all of the factors mentioned above were either less-satisfied (35\%) or dissatisfied
(40\%) (Figure7 \& 8). The factors that worked behind low satisfaction and dissatisfaction are improper, inadequate, non-standard, and irregular safety and negligence and financial crisis of their organizations. Highly satisfied journalists (25\%) said that their employers had provided sufficient safety measures in comparison with other media organizations.

The impact of improper safety measures has contributed significantly to self-preparedness and the perception of journalists about infection and the death of journalists in Bangladesh that the last research question dealt with. $73 \%$ of journalists bought safety equipment by own while $45 \%$ bought due to lack of proper safety equipment provided by offices. 90\% of journalists thought that a lack of adequate safety measures was responsible for infection and the death of journalists in Bangladesh. Highly satisfied journalists said, they thought that other media organizations didn't provide safety measures to employees as their organizations did.

The contribution of improper safety measures is prevalent in the unequal distribution of safety measures between reporters and copyeditors. The study suggests that no media organization could not provide safety equipment and safe atmosphere and economic safety to both reporters and copy editors equally. Copy editors got less PPE and gloves, and less opportunity to work at home in comparison with reporters (Figure 12 \& 13). Suffering from the economic crisis was the same in both. The result shows that a complete balance and equality in providing safety equipment, a safe 
atmosphere, and paying salaries and bonuses were not found in any media organization. In this case, the copy editors have faced discrimination more than the reporters. (Figure 12 \& 13). Thus, copy editors' dissatisfaction, and low satisfaction are higher than that of reporters (Figure $15 \& 16$ ).

The result shows, the majority of the participants thought that improper and inadequate safety measures are responsible for the infection and death of journalists. This perception is more pervasive in copy editors than reporters (Figure 18). However, selfpreparedness showed different results. Despite getting less equipment, copy editors had a lower frequency of buying it than reporters. The reason behind this result will be evaluated in future research.

Overall, the findings of the study reflected the imbalanced management system of media organizations in providing safety to journalists in corona times. The employers have no equal and proper safety policies that contributed negatively to psychology and particular behavior of the majority of journalists regarding safety measures. The organizations failed to maintain equity and fairness between reporter and copy editor and lacked unity of directions, proper initiative. Finally, employers failed to respond effectively to the needs of journalists.

Media played a pivotal role in corona times in equipping the public with information for disease prevention (Meija et al., 2020). Gidreta (2011) characterized the journalist as a "mediator" ", "teacher", and "guide" in terms of conveying information to the public (pp. 62-63). In corona times, journalists have performed these roles. Antonio Guterres, the UN Chief, branded journalists as "antidote" to the COVID-19 misinformation (UN News, 2020b). The study noticed that selected journalists continued their activities as per professional requirements and responsibilities in playing those roles to fight the pandemic. Nevertheless, they suffered from proper safety measures in corona times. Media organizations also ignored the tips and guidelines prescribed by scholars and organizations. This observation of the study fits to saying of Rahman (2006b), "'In Bangladesh, journalism is not only a challenging profession, but it becomes a sacrificial one ' (p.20).

The findings of the study have also indicated that the non-professional practice of the Bangladeshi media industry. Gayen (2019) observed the media of Bangladesh that " mainstream journalism suffers from lack of funding and lack of professionalism " . Ferdous (2009) argued that the businessman, groups of companies, and politically influential persons control the media ownership where their interests of profits are prioritized rather than interests of mass people (p.19). Journalist associations can't put challenges to " the power" ' and "the business conglomerates" ' due to their fractions (Gayen, 2019). Thus, the interests of journalists in Bangladesh remain mostly ignored and unchallenged.

Nevertheless, the safety of journalists is not an advantage; it is their fundamental human rights that organizations or industries are obliged to provide (Hilgert, n.d., p. 720). The Resolution adopted by the Human Rights Council in 2016, emphasized on protective equipment, training, digital security, guidance and insurance that should be provided by media organizations where necessary (Article 19, 2017, p.34). Occupational Safety and Health Convention (1981), emphasize son "necessary, adequate protective clothing and protective equipment " to employees to prevent risks. United Nations announced the safety of employees (United Nations, 1998; UN General Assembly, 1966). In Bangladesh, the safety of employee is legally ensured (Bangladesh Labor Act, 2006). Whereas journalists speak for the human rights of mass people, their rights remain ignored always. The study showed that media organizations violated human rights of two-thirds of selected journalists.

There is also no proper monitoring system form government and non-government policymakers and journalist's associations to protect the rights of journalists. Bangladesh's government has addressed the role of media in corona times in "National Preparedness and Response Plan for Covid-19' '. However, there is no direction to organizations regarding their safety protocols. All of these issues have appeared as obstacles to build professionalism in media organizations and ensure journalists' rights and needs.

\section{Xi. Conclusion and Recommendations}

In the last decade, media in Bangladesh has undergone remarkable growth and changes in terms of expansion and increase in more young journalists (Monty, 2011). Education and training on journalism in universities and professional institutions are also playing a vital role in changing the face of media. Apart from the increase in information flow for the development of the country, the role of media in Bangladesh in times of disaster and crisis is undeniable. However, little progress has been made to ensure professionalism and develop the standard of living and safety of journalists here. The study unfolded this approach to journalists that has been practiced years after years.

In any disaster, epidemic, or pandemic, journalists work as front-runners. Therefore, it should be the core responsibility of media houses to equip them with all of the health protections. Corona times have witnessed how journalists have provided information to the public and risked their lives. The study revealed that the efforts taken by the employers to ensure the safety 
of journalists in corona times could not be equalized with what they have deserved. Akhter and Ullah (2014) mentioned that the danger of journalists in disastrous times might influence the information flow of media (p.10).

So, it is high time for government and media employers to have a proper plan and policies with huge budgets and logistic supports to protect journalists from any type of risks. Practices of professionalism and providing facilities and safety to journalists by national and international legal issues must be addressed with high importance.

The study did not incorporate how the lack of proper safety measures influenced their news coverage on Corona. Besides, the study incorporated the Dhaka area with limited samples. It also didn't include gender issues, other media organizations such as online media, radio, etc. and other employees like a camera crew, photojournalists, etc. The future research will shed light on these scopes by mitigating the limitations of the study.

\section{References Références Referencias}

1. Adriano, J. (2020, March 2). Journalism in the time of the coronavirus. Sci Dev Net. Retrieved from https://www.scidev.net/global/health/scidev-net-atlarge/journalism-in-the-time-of-the-coronavirus1x.html?

2. Akhter, R., \& Ullah, M. S. (2014). News coverage of cyclones and risk exposure of journalists in Bangladesh. Mass Communicator: International Journal of Communication Studies, 8(3), 4-11. https://doi.org/10.5958/0973-967X.2014.00001.5

3. Akrani, G. (2011). Administrative Management Theory, School-Henry Fayol. Retrieved from https:// kalyan-city.blogspot.com/2011/06/administrativemanagement-theory- school.html

4. Allsop, J. (2020, March 17). How journalists around the world are covering the coronavirus. Columbia Journalism Review. https://www.cjr.org/the_media today/coronavirus_uk_italy_france_south_korea.php

5. Article 19. (2017). Acting on UN Human Rights Council Resolution 33/2 on the Safety of Journalists [PDF File]. Article 19. Retrieved from https://www. article19.org/wp-content/uploads/2017/11/safety of journalists WEB 23.10.pdf

6. Bangladesh Labor Act (2006) [PDF file]. Retrieved from https://www.ilo.org/dyn/travail/docs/352/A\%20 Handbook\%20on\%20the\%20Bangladesh\%20Labour \%20Act\%202006.pdf

7. Biswas, S. (2020, May 4). How Covid-19 is ravaging India's newsroom. BBC News. https://www.bbc. com/news/world-asia-india-52464029?prompt

8. Boasiako, K. A. (2017). Reporting Health Emergency Outbreaks: African Journalists on the Frontlines of Ebola Coverage [PDF File]. (Doctor of Philosophy
Dissertation) Retrieved from https://etd.ohiolink. edu/!etd.send_file?accession=ohiou149093953969 4056\&disposition =inline

9. Brayne, M. (2007). Covering Traumatic Events in Community. In M. Brayne (Ed) TRAUMA \& JOURNALISM A Guide For Journalists, Editors \& Managers [PDF file], 8-18, Retrieved from https:// dartcenter.org/sites/default/files/DCE_JournoTraum aHandbook.pdf

10. Dominick, Joseph R. (2009). The Dynamics of Mass Communication, Media in the Digital Age $\left(10^{\text {th }}\right.$ ed.). McGraw-Hill.

11. Edimo, A. (2016, May 17). In the Backstage of the 2014 Ebola Crisis News Coverage: A Focus on the Lived Experience of Involved African Journalists [PDF file]. Master's Thesis. Retrieved from https:// spectrum.library.concordia.ca/981299/1/Edimo_MA F2016.pdf

12. Ferdous, R. (2009). Gonomaddhom: Rajnoitik Orthoniti o Khomota Prosno (Mass Media: Political Economy and Question of Power). In R. Ferdous (Ed.), Gonomaddhom/Srenimaddhom (Mass Media/Class Media). pp. 13-26. Srabon Prokashoni.

13. Gayen, K. (2019, Nov. 19), (Uncertain) Future of Journalism in Bangladesh, The Daily Star. https://www.thedailystar.net/star-weekend/news/ uncertain-future-journalism-bangladesh-1833094

14. Gidreta, A. D. (2011). Development Communication, Acceptability and Implementation. VDM Verglag Dr. Muller $\mathrm{GmbH} \& \mathrm{Co}$. Kg.

15. GIJN. (2020). Tips for Journalists Covering COVID19. GIJN. Retrieved from https://gijn.org/2020/ 03/10/tips-for-journalists-covering-covid-19

16. Godwin, A. Handsome, O. E., Ayomide, W. A., Enobong, A. E. \& Johnson, J. F. (2017), Application of the Henri Fayol Principles of Management in Startup Organizations, IOSR Journal of Business and Management, 19 (10), 78-85. DOI: 10.9790/ 487X-191004788

17. Hasan, M. \& Wadud, M. (2020). Re-Conceptualizing Safety of Journalists in Bangladesh [PDF file]. Media and Communication, 8 (1), 27-36. https://doi.org/ 10.17645/mac.v8i1.2494

18. Haider, J. (2014). BangladesherShongbadpotro o Shangbadikota[Newspaper and Journalism of Bangaldesh]. NobojugProkashoni.l

19. Hashim, A. (2020, May 11). Journalist on front line of Pakistan's coronavirus outbreak. Aljazeera. https:// www.aljazeera.com/news/2020/05/journalists-frontline-pakistan-coronavirus-outbreak-20051111523 1799.html

20. Hilgert, J. (n. d.). THE Future Of Workplace Health and Safety as a Fundamental Human Right [PDF file]. Comparative Labor Law \& Policy Journal, 34(3), 715-736. Retrieved from http://www.corteidh.or.cr/ tablas/r31681.pdf 
21. Hooker, C., King, C. \& Leask, J. (2011). Journalists' views about reporting avian influenza and a potential pandemic: a qualitative study. Influenza and Other Respiratory Viruses 6(3), 224 - 229. https://doi.org/10.1111/j.1750-2659. 2011. 00319.X

22. Hou, Y., Tan, Y., Lim, W. Y., Lee, V., Tan, L. W. L., Chen, M. C. \& Yap, P. (2018). Adequacy of public health communications on $\mathrm{H} 7 \mathrm{~N} 9$ and MERS in Singapore: insights from a community based crosssectional study. BMC Public Health 18, 436, 1-11. http://doi.org/10.1186/s12889-018-5340-x

23. Huda, K. N. \& Azad A. K. (2015a). Professional Stress in Journalism: A Study on Electronic Media Journalists of Bangladesh. Advances in Journalism and Communication, 3(4), 79-88. http://dx.doi.org/ 10.4236/ajc.2015.34009

24. Huda, K. N. (2018b). Job Stress among the Newspaper Reporters in Bangladesh. National Institute of Mass Communication Journal, 2(2), 131-147.

25. IEDCR (2020). Covid-19 Status Bangladesh. IEDCR. Retrieved from https://www.iedcr.gov.bd

26. Inqilab (2020, April 17). Shangbadikder Jhuki Vata o Bokea Beton Din, DUJ-er bibriti [Pay risk allowance and due salary to Journalists, DUJ (Dhaka Reporters Unity) Statement]. The Daily Inqilab. Retrieved from https://www.dailyinqilab.com/article/ 284261/সা ংব দকিদর -বুঁদক-ভ ত -ও-বদকয় ববতন-

27. IWMF (2016). An Overview of the Current Challenges to the Safety and Protection of journalists [PDF file]. IWMF Retrieved from https://en.unesco.org/sites/default/files/iwmf unesc o paper.pdf

28. Jamil, S. (2019). Culture of impunity and safety of journalists: Is safe journalism a distant dream in Pakistan? World of Media. Journal of Russian Media and Journalism Studies, 1, 51-66. http://dx.doi.org/ 10.30547/worldofmedia.1.2019.3

29. Kwok, A. C. F. (2014), The Evolution of Management Theories: A Literature Review [PDF file], Nang Yan Business Journal, 3(1), 28-40. Retrieved from https://www.researchgate.net/publication/307760441 The Evolution of Management Theories A Literat ure Review

30. Maswood, M. (2020, April 26). Bangladesh far behind South Asian countries. The New Age.A1-A2

31. Meija, C. R., Ticona, D., Alarcon J. F. R., Urbina A. M. C., Medina, J. B. C., Quinto, T. P...Palone M. R. T. (2020). The Media and their Informative Role in the Face of the Coronavirus Disease 2019 (COVID19): Validation of Fear Perception and Magnitude of the Issue (MED-COVID-19). Electronic Journal of General Medicine 2020, 17(6), em239. https://doi. org/10.29333/ejgm/7946
32. Mierzjewska, B. I. \& Hollifield, C. A. (2006). Theoretical Approaches in Media Management Research. In A. B. Albarran, S. M. Chan-Olmsted \& M. O. Wirth (Ed.), Handbook of Media Management and Economics, pp. (37-66). Routledge.

33. Monty, A. N. (2011, Feb.). Press Freedom has its limitations in Bangladesh. Committee to Protect Journalists (CPJ). https://cpj.org/2011/02/pressfreedom-has-its-limitations-in- bangladesh/

34. Moore, T., \& Rakha, R. (2002). Tolley's Handbook of Disaster and Emergency Management ( $3^{\text {rd }}$ ed.). Routledge.

35. Murthy, C. S. H. N. (2018). Safety and Security of Journalists: Yet Awaiting Intervention from Indian Academy and Industry. Asia Pacific Media Educator, 28(1). 131-149. http://doi.org/10.1177/1326365X18 772359

36. Nabi, M. S. (2020, April 12). Coronavirus: What about the safety of journalists on the frontlines?, Dhaka Tribune. https://www.dhakatribune.com/ health/coronavirus/2020/04/12/what-about-thesafety-of-journalists-on-the-frontlines-of-covid

37. Olorunda, S. (2019). Media \& Journalism: Safety Level of Journalist in times of Election in Southwest Nigeria [PDF file]. Retrieved from https://www. researchgate.net/publication/332060634_Media_Jo urnalism_Safety_Level_of_Journalist_in_times_of_El ection_in_Southwest_Nigeria

38. Ophir, Y. (2018). Spreading News: The Coverage of Epidemics by American Newspapers and Its Effects on Audiences: A Crisis Communication Approach. (Doctor of Philosophy Dissertation). Publicly Accessible Penn Dissertations.2787. Retrieved from https://repository.upenn.edu/cgi/viewcontent.cgi? article $=4573 \&$ context $=$ edissertations

39. Piotrow, P. T., Kincaid, L., Rimon, J. G. \& Rinehart, W. (1997). Health Communication. Praeger Publishers.

40. Potter, D. \& Ricchiardi, S. (2009). Disaster and Crisis Coverage [PDF file]. Retrieved from https://www. rcmediafreedom.eu/Publications/Manuals/Disasterand-Crisis-Coverage-a-manual-for-journalists

41. Rahman, M. (2020a, May 11). Covid-19: 127 journalists infected so far in Bangladesh. Dhaka Tribune. https://www.dhakatribune.com/health/ coronavirus/2020/05/17/covid-19-127- journalistsinfected-so-far-in-Bangladesh

42. Rahman, G. (2006b). Communication in Bangladesh, Media Response and Campaign Strategy. Shrabon Prokashani.

43. Reporters without Borders and UNESCO (1992). Safety Guides for Journalists [PDF file]. United Nations Educational, Scientific and Cultural Organization. Retrieved from https://rsf.org/sites/ default/files/2015-rsf-safety-guide-for-journalists.pdf 
44. Sauer, L. M. (2020, May 29). What Is Coronavirus? Johns Hopkins Medicine. Retrieved from https:// www.hopkinsmedicine.org/health/conditions-anddiseases/coronavirus

45. Sing, S. \& Goyal. Er. J. (2016). Analysis of Safety Measures at Construction Sites. International Journal of Advance Research, 4(10), 425-430. Retreived from https://www.academia.edu/29952604/ ANALYSIS_OF_SAFETY_MEASURES_AT_CONSTR UCTION_SITES

46. Skliarov, S., Kaptan, K. \& Manesh, A. K. (2017). Definition and general principles of disasters. In A. K. Manesh (Ed.), Handbook of Disaster and Emergency Management (pp.17-22). Kompendiete.

47. Sreedharan, C., Thorsen, E., \& Sharma N. Sreedharan (2019), DISASTER JOURNALISM: Building media resilience in Nepal. Anweshan Pvt Ltd.

48. Steffens, M., Wilkins, L., Vutee, F., Thorson, E., Kyle, G. \& Collins, K.(2012). Reporting Disaster on Deadline. Routledge.

49. Swapan, H. U. R. (2017, August 9). ShangbadikderBeton Koto? (How much salary journalistsreceive?). DW. https://www.dw.com/bn/ বাংল দশ্রে -স ংব দকিদর র-বতেন-কত/a-40025632

50. Thomas, K. \& Senkepi, A. D. (2020). What Should Health Science Journalists Do in Epidemic? [PDF file]. AMA Journal of Ethics, 22 (1), 55-60. Retreived from https://journalofethics.ama-assn.org/sites/ journalofethics.ama-assn.org/files/2019-12/msoc12001_0.pdf

51. Tirintetaake, I. (2017), Scientific Management Theory vs. Human Relations Theory [PDF file]. Retrieved from https://www.researchgate.net/ publication/316464967_Scientific_Management_The ory_vs_Human_Relation_Theory

52. TRT World (2020, April 27). Corona Times: The impact of Corona on Media Industry [Video file]. Retrieved from https://www.youtube.com/watch? Reload $=9 \& v=$ MJaHOfSgz-Al

53. UN General Assembly (1966). International Covenant on Economic, Social and Cultural Rights, art. 7, Dec. 16, 1966, 993 U.N.T.S. 3. Retrieved form https://www.ohchr.org/en/professionalinterest/page s/cescr.aspx

54. UN News (2020a, April 13). During this coronavirus pandemic, 'fake news' is putting lives at risk: UNESCO. UN News. Retreived from https://news. un.org/en/story/2020/04/1061592

55. UN News (2020b, May 1). Journalists provide 'antidote' to COVID-19 misinformation, UN chief says ahead of World Press Freedom Day. UN News. https://news.un.org/en/story/2020/05/1063012

56. UNESCO (2020). UNESCO stresses importance of safety of journalists amid COVID-19 pandemic. UNESCO. Retrieved form https://en.unesco.org/ news/unesco-stresses-importance-safetyjournalists-amid-covid-19-pandemic

57. Unicef (2020). A set of safety guidelines issued for all journalists who may be more vulnerable to contracting COVID-19. Unicef. Retrieved from https://www.unicef.org/india/coronavirus/safetyguidelines-journalists-reporting-covid-19

58. United Nations. (1998). The Universal Declaration of Human Rights, 1948-1998. United Nations Dept. of Public Information.

59. WHO (2020). Coronavirus disease (COVID-19) Pandemic. WHO. https://www.who.int/ emergencies/ diseases/novel-coronavirus-2019 